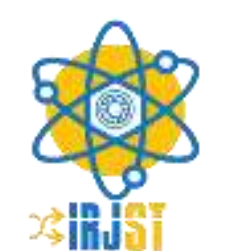

Available online at https://www.irjst.com/

International Research Journal of Science and Technology

ISSN: 2707-3955

DOI: https://doi.org/10.46378/irjst.2021.020206

\title{
Malathion Prompted Genotoxicity Assessment in rDNA ITS1 and ITS2 Sequence of Anopheles stephensi
}

\author{
Reshma Sinha*, Preety Bhinder \\ Department of Zoology, Panjab University, Chandigarh-160014, India
}

\begin{tabular}{|c|c|}
\hline Paper Status & \\
\hline Received & Dec2020 \\
\hline Accepted & Feb 2021 \\
\hline Published & Mar 2021 \\
\hline
\end{tabular}

Key Words

Anopheles

Genotoxicity

Malathion

Mutation

PCR

\begin{abstract}
Indiscriminate use of pesticides in agricultural practices has developed its toxicity in humans and animals exposed to it. Malathion is a non-systemic insecticide belonging to organophosphate class. It is used in controlling Mediterranean flies, bugs, and aphids in fields. The present study was aimed to evaluate the malathion induced genotoxicity in Internal transcribed spacer, ITS 1 and 2 sequences of rDNA of mosquito, Anopheles stephensi. For this, second instar larvae of mosquito were exposed to $2.54 \mathrm{ppm}$ (LC20) of malathion for an acute period of 24h. Post-treatment, larvae were allowed to develop into adults, and Internal transcribed spacer (ITS) sequences of rDNA were amplified by Polymerase chain reaction (PCR). PCR amplification revealed significant point mutations in form of transition, transversion, deletion and insertion in treated ITS 1 and 2 sequences compared to control. ITS 1 sequence showed deletion of 26 bases, insertion of 141 bases, and substitutions of 236 bases compared to control. While, treated ITS 2 sequence suffered 48 deletions, 54 insertions, and 117 substitutions of nucleotide compared to non-treated mosquito sequences. ITS 1 was found to be more affected by malathion toxicity with lowered GC content. Thus, present study details the toxicity of pesticide in the mosquito, Anopheles stephensi, contributing to the field of toxicology.
\end{abstract}

Copyright (c) 2021: Reshma Sinha and Preety Bhinder. This is an open-access distribution, and reproduction in any medium provided Access article distributed under the Creative Commons Attribution License the original work is properly cited License, which permits unrestricted use.

Citation: Reshma Sinha and Preety Bhinder. "Malathion Prompted Genotoxicity Assessment in rDNA ITS1 and ITS2 Sequence of Anopheles stephensi" International Research Journal of Science and Technology, 2(2), 406-412. 2021.

\section{Introduction}

The exploding population has developed the concept of increased productivity through the worldwide use of fertilisers and pesticides. Pesticides play its role by controlling pests, weeds, insects, microbes, fungus, and weeds in the fields and on the crops. India accounted for annual production of approximately 217 , 000 metric tons in 2019 with 3rd position in chemical production in Asia [1]. Organophosphates are an important class of pesticides that act by inhibition of neuromuscular enzyme, acetylcholinesterase. Malathion is a non-systemic insecticide used in agricultural fields controlling aphids, bugs, Mediterranean flies, etc.

* Corresponding Author: Reshma Sinha

Department of Zoology, Panjab University, Chandigarh, India.

Email: sinhareshma89@gmail.com
Malathion has been reported to cause toxicity in animals, fish, and insects[2, 3, 4,5]. It is also used as a topical treatment for head lice, fumigation, veterinary practices, domestic and public health purpose [6,7]. Because of its low mammalian toxicity malathion becomes one of the most commonly used organophosphate compounds and hence a major source of environmental hazard $[8,9]$. In the environment, it raises concern due to persistence for a longer period having hydrolysis half-life of 10 days [10].

Pesticide interacts with the DNA of living organisms by conversion to more reactive intermediates or electrophiles affecting genetic material, cells, and tissues. This has created an urgent need to evaluate the harmful effects of these chemicals on the structure and function of biological systems as they possess clastogenic activities [11,12]. 
Amplification of sequences from whole DNA using primers aide in the assessment of genotoxicity. rDNA gene is conserved sequences used for molecular profiling and toxico-genomics. rDNA comprises of $18 \mathrm{~S}, 5.8 \mathrm{~S}$, and $28 \mathrm{~S}$ gene coding for rRNA [13]. ITS spacer sequences are located in the form of tandem repeated multigene families in the eukaryotic rDNA gene [14]. Mature rDNA gene is produced by processing of large precursor from which different transcribed regions are sequentially removed through an elaborate pathway of cleavage steps [15]. Although they form part of introns yet the transcribed spacer regions are known to play an important role in the coding of required rRNA and for the control of ribosome biogenesis [16]. Keeping these in view, present research work was carried out to evaluate the genotoxicity in ITS 1 and 2 sequences of Anopheles stephensi on exposure to malathion.

\section{Material and Methods}

\subsection{Test organism, collection and rearing}

Larvae of Anopheles stephensi belonging to the family Culicidae (Order Diptera) were collected from the river Ghaghar, Chandigarh. The collection was done in seasons of high availability (September to December). The second instar larvae were fed on a protein-rich diet, consisting of finely powdered dog biscuit and yeast extract in the ratio of $6: 4[17,18]$.

\subsection{Toxicant used and treatment}

Malathion (C10H1906PS2) (50\%EC) belonging to organophosphate class was purchased from Scientific Fertilizers Co. Pvt. Ltd., Coimbatore, India. For the effective dose determination, LC20 was determined using Probit analysis [19]. For this, second instar larvae $(n=20)$ each was exposed to successive serial dilution (10-2 to $10-11 \mu \mathrm{l} / \mathrm{ml})$ of malathion for $24 \mathrm{~h}$. Simultaneously, parallel controls were maintained in pesticide free distilled water. Triplicates of each dilution were maintained and the percentage mortality was calculated from the survival rate of treated larvae. LC20 value of malathion for Anopheles stephensi came to be $2.54 \quad \mathrm{X} \quad 10-4 \quad \mu \mathrm{l} / \mathrm{ml}$ with regression equation ( $\mathrm{Y}=10.62+0.52 \mathrm{X})$ using SPSS-18. Finally, second instar larvae were treated with $2.54 \mathrm{X}$ $10-4 \mu \mathrm{l} / \mathrm{ml}$ of malathion for $24 \mathrm{~h}$ and larvae were then transferred to the pesticide-free distilled water for the completion of their life cycle and to develop as adults.

\subsection{DNA extraction, PCR amplification, sequencing of ITS 1 and ITS 2}

The DNA was extracted from the whole-body homogenate of the mosquitoes by the phenolchloroform extraction method of Ausubel et al. [20] and stored at $-20^{\circ} \mathrm{C}$ till further use. Each set of PCR amplification reactions contained DNA template, oligonucleotide primers for ITS 1 and 2 (Table 1), 1X PCR buffer, Taq polymerase (1U), double distilled water, $\mathrm{MgCl} 2$, and dNTPs mix. PCR amplification was carried out in Thermocycler (Biometra Personal) programmed for 37 cycles under detailed conditions (Table 2). PCR products were analyzed on horizontal gel electrophoresis with a gene ladder (100bp). The amplified sample of DNA was sent for sequencing to Chromos Biotech Pvt. Ltd, Bangalore. These were sequenced with the help of the Big Dye terminator cycle sequencing kit (version 3.1) of Applied Biosystems. Finally, DNA sequences were aligned using Clustal W, and results were interpreted.

Table 1. Details of primers used for amplification of ITS 1 and ITS 2

\begin{tabular}{llll}
\hline & Primer & Sequence & Reference \\
\hline & Forward & 5'-CCTTTGTACACACCGCCCGT-3' & Shouche and \\
\cline { 2 - 4 } ITS1 & Reverse & 5'-GTTCATGTGTCCTGCAGTTCAC-3' & Patole [21] \\
\hline \multirow{3}{*}{ ITS2 } & Forward & 5'-TGTGAACTGCAGGACACAT-3' & Porter and Collin \\
\cline { 2 - 4 } & Reverse & 5'-TATGCTTAAATTCAGGGGGT-3' & [22] \\
\hline
\end{tabular}

Table 2. Details of PCR conditions

\begin{tabular}{cllc}
\hline Steps & Process & Time & Temperature \\
\hline 1. & Initial denaturation of DNA $(1$ cycle $)$ & 10 minute & $94^{\circ} \mathrm{C}$ \\
\hline & 36 cycles steps & & \\
\cline { 2 - 4 } 2. & Denaturation of DNA & 1 minute & $94^{\circ} \mathrm{C}$ \\
\cline { 2 - 4 } & Annealing of primers & 1 minute & ITS $1-56^{\circ} \mathrm{C}$, ITS $2-59^{\circ} \mathrm{C}$ \\
\cline { 2 - 4 } & Extension & 1 minute & $72^{\circ} \mathrm{C}$ \\
\hline 3. & Final extension $(1$ cycle $)$ & 10 minute & $72^{\circ} \mathrm{C}$ \\
\hline
\end{tabular}




\section{Result and Discussion}

ITS 1 and ITS 2 sequence of rDNA of control and treated individuals of Anopheles stephensi subjected to PCR amplification elucidated alterations in the form of insertion, deletions, transition, and transversion of bases. ITS 1 and ITS 2 PCR amplification generated product of approx. 600 and 400bp respectively (Fig. 1 and 3). Clustal W aligned sequence generated congruent results, and loci marked with the asterisk (*) depicted identical bases in both the sequences. While, loci marked with dashes (-) in control sequence indicated bases differing due to insertion, and dashes in treated sequences exhibited deletion. The region of base sequences not indicated by the asterisk or dash indicated transition and transversion (Fig. 2 and 4). Comparative study of the two sequences provided considerable incidence of mutation induced by malathion. A comparison of total base-pair length of ITS 1 sequence from control individual produced a band of 585bp as compared to 700bp from the treated sequences. The average G: C content was $52 \%$ and $47 \%$ in control and treated sequences respectively.
While an average A: T content was found to be $48 \%$ and $53 \%$ in the control and treated sequences respectively. Additionally, observed deletion of 26 bases and insertion of as many as 141 bases, with a high frequency of substitutions comprising of 138 base transitions and 98 base transversion (Table 3 ).

Similarly, a comparison between normal and induced ITS 2 sequences had a total base-pair length of 414 bases and 420 bases respectively. The percentage of G: $\mathrm{C}$ content was $57 \%$ and $58 \%$ from the control and treated individuals respectively. While the A: T content was $43 \%$ for control and $42 \%$ for the treated stock. Further the base comparison revealed deletion of 48 bases and insertion of 54 . Moreover noticed 71 transition and 46 transversion, instances of making it a total of 117 base substitutions (Table 3). The data deciphered significantly higher incidences of the point mutation in the ITS 1 sequence, with a total number of 403 base mutation compared to 219 bases of ITS 2 sequence. Thus, inferring disturbed splicing mechanism and ribosome biogenesis.

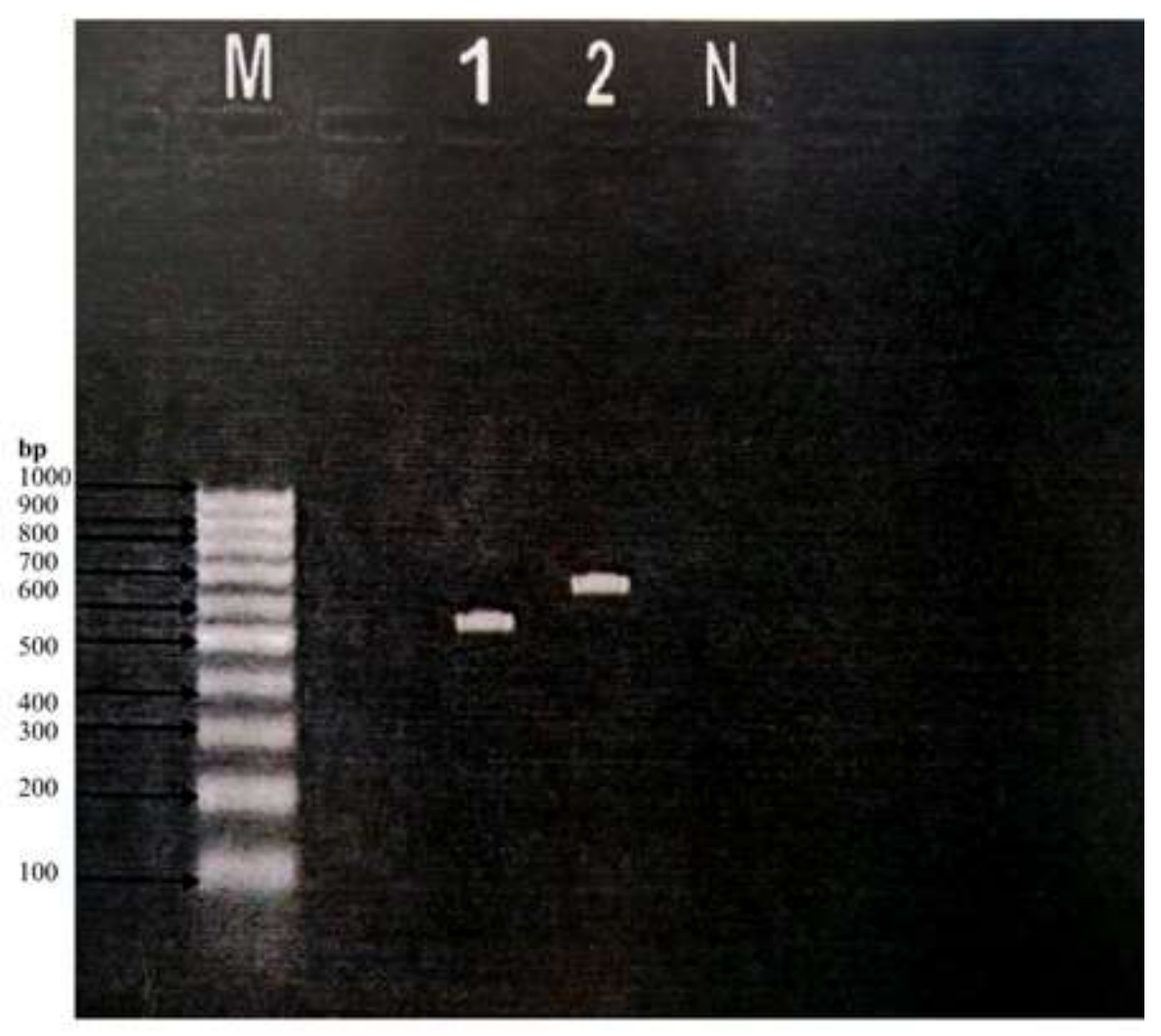

Fig. 1. PCR generated DNA bands from ITS1 of control and treated individuals.

Lane M-DNA ladder; Lane 1- DNA band from control; Lane 2- DNA band from treated; Lane $\mathrm{N}$ - Negative control. 


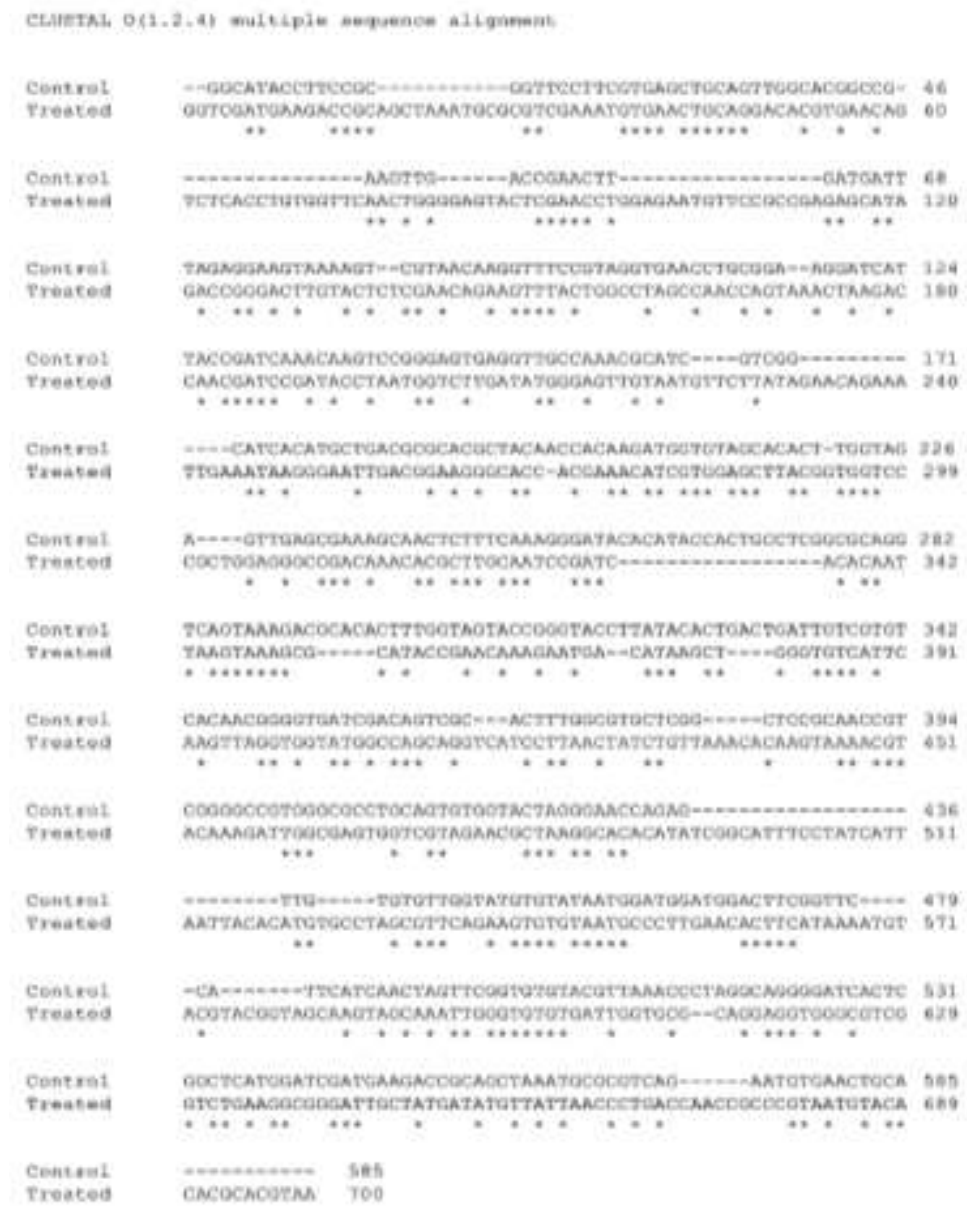

Fe. 2. Sequesce comparison of Intermal Transeribed Spacer 1 (ITS I) of control and treated stoeks or Amopheles stephews.

Loti marked with the asterisk (*) indisates identical bases in both the sequenees.

Loci marked with dashes (- ) in control sequence indicates insertion and dashes in treated sequences indicates deletion. The region of base sequences not indicated by the asterisk or dash indicates tramition and transversion

Table 3. Sequence characteristic of ITS 1 and 2 sequences of control and treated Anopheles stephensi

\begin{tabular}{clllll}
\hline \multirow{2}{*}{ S. No. } & \multirow{2}{*}{ Parameter } & ITS 1 & & ITS 2 & \\
\cline { 3 - 5 } & & Control & Treated & Control & Treated \\
\hline 1. & Total length of sequence & 585 & 700 & 414 & 420 \\
\hline 2. & Total no. of bases mutated & - & 393 & - & 219 \\
\hline 3. & G:C content & $52 \%$ & $47 \%$ & $57 \%$ & $58 \%$ \\
\hline 4. & A:T content & $48 \%$ & $53 \%$ & $43 \%$ & $42 \%$ \\
\hline 5. & No. of deletions & - & 26 & - & 48 \\
\hline 6. & No. of insertions & - & 141 & - & 54 \\
\hline 7. & No. of transition & - & 138 & - & 71 \\
\hline 8. & No. of transversion & - & 98 & - & 46 \\
\hline
\end{tabular}

Upon metabolization in animal body malathion degrades into malaoxon, potentially more toxic analogue inhibiting acetyl-cholinesterase thus eliciting hyperactivity, restlessness, and finally death [23, 24]. Studies have detailed its toxicity with varying intensity in insects, invertebrates, and fish [3, 25, 26, 27, 28]. It has been documented to persists for 11 to 14 days, ranging $52-21 \%$ level in river water [29]. Lien et al. [30] have reported developmental deformities in the form of the deformed notochord and pericardial oedema in $C$. gariepinus larvae exposed to malathion .
Bhinder and Chaudhry [31, 32] elucidated altered restriction enzyme digestion sites upon organophosphate treatment in Culex quinquefasciatus. Temperature acts as important factor in enhancing malathion toxicity [27, 33,34]. The insecticide has been reported to affect various tissue such as liver, kidney, and testicles in rats $[35,36,37,38]$. 

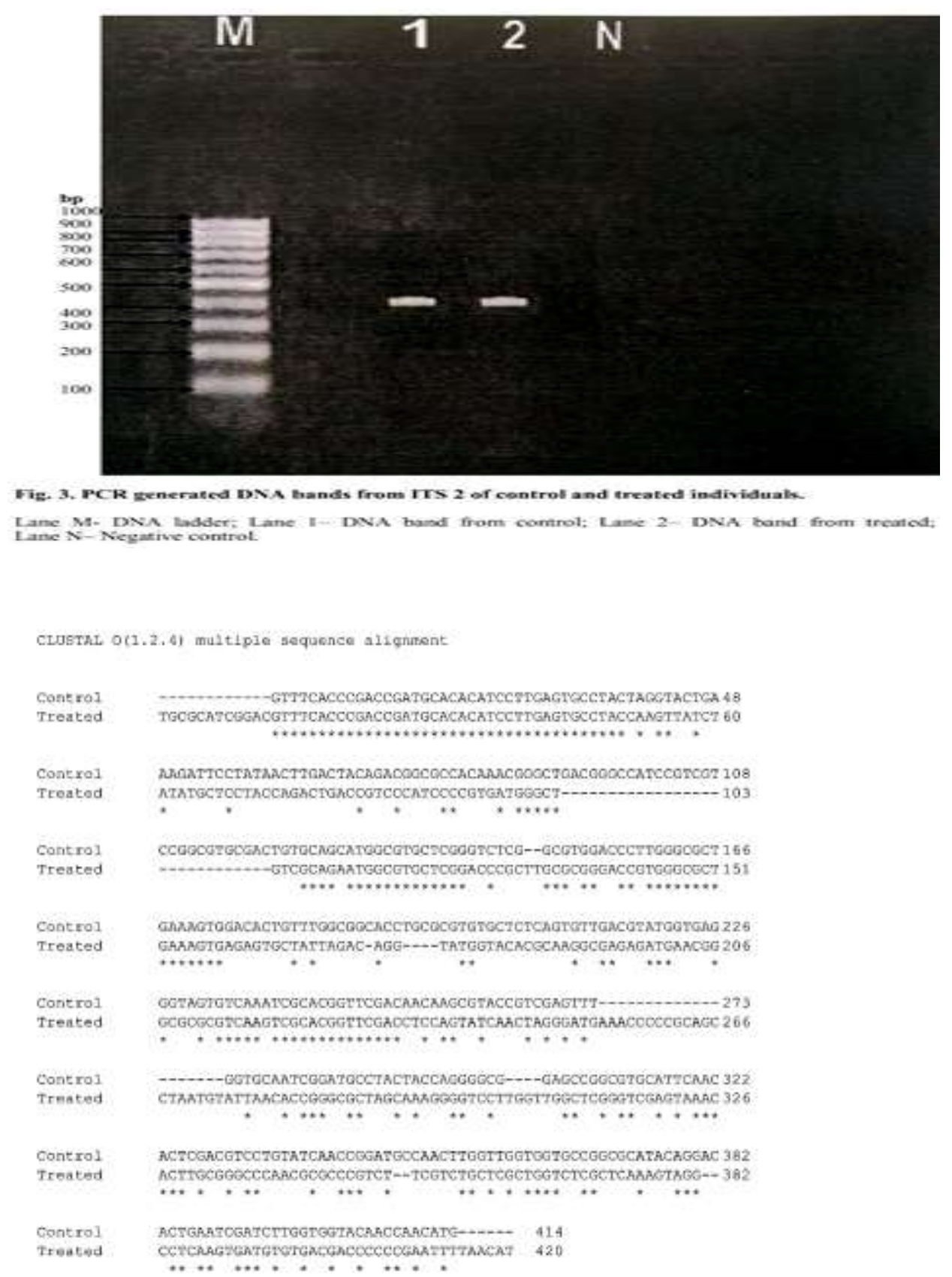

Fig. 4. Sequence comparisen of Internal Transeribed Spacer 2 (ITS 2) of control and treated stocks of Anopheles stephensi.

Loci marked with the asterisk (*) indicates identical bases in both the sequences.

Loci marked with dashes (-) in control sequence indicates insertion and dashes in treated sequences. indicates deletion. The region of base sequences not indicated by the asterisk or dash indicates transition and transversion

Additionally, Al-Attar [39] reported damaged histoarchitecture and elevated activities of serum enzymes GOT, GPT, ALP, ACP, and levels of creatinine, urea, and uric acid, while depressed levels of total protein and total albumin in malathion exposed rats. Kumar et al. [40] demonstrated damaged DNA in gill, kidney, and lymphocytes of Channa punctatus. A linear relation between exposure time and DNA damage has been elucidated in Oncorhynchus mykiss [5, 41].

\section{Conclusion}

Malathion exposure induced mutations in ITS 1 and ITS 2 sequences of rDNA in the form of deletion, insertion, transition, and transversion in Anopheles stephensi. Comparison of the non- treated and treated sequences through Clustal W reflected ITS 1 as more affected. Thus, it can be concluded that the PCR technique in combination with ITS sequences 
developed pathways for genotoxicity evaluation in a reliable way.

\section{References}

[1]. Statista (2020). Pesticides production volume in India 2014-2019. Published by Statista Research Department, Nov 14, 2019. Last accessed on 11-04-2020.

[2]. Abdel-Daim, M.M., Abushouk, A.I., Bungău, S.G., Bin-Jumah, M., El-Kott, A.F., Shati, A.A., Aleya, L., Alkahtani, S. (2020). Protective effects of thymoquinone and diallyl sulphide against malathion-induced toxicity in rats. Environment Science Pollution Research, 27(10), $10228-10235$. https://doi.org/10.1007/s11356-019-07580-y.

[3]. Guo, D., Wang, Y., Qian, Y., Chen, C., Jiao, B., Cai, L., Wang, Q. (2017). Joint acute and endocrine disruptive toxicities of malathion, cypermethrin and prochloraz to embryo-larval zebrafish, Danio rerio. Chemosphere, 166, 6371.

[4]. Meng, L.-W., Peng, M.-L., Chen, M.-L., Yuan, G.-R., Zheng, L.-S., Bai, W.-J., Smagghe, G. and Wang, J.-J. (2020), A glutathione S-transferase (BdGSTd9) participates in malathion resistance via directly depleting malathion and its toxic oxide malaoxon in Bactrocera dorsalis (Hendel). Pest Management Science, doi:10.1002/ps.5810

[5]. Ullah, S., Begum, M., Ahmad, S., Dhama, K., (2016a). Genotoxic effect of endosulfan at sublethal concentrations in mori (Cirrhinus mrigala) fish using single cell gel electrophoresis (comet) assay. International Journal of Pharmacology,12, 169-176.

[6]. Pluth, J.M., O'Neill, J.P., Nicklas, J.A., Albertini, R.J. (1998). Molecular bases of hprt mutations in malathion-treated human Tlymphocytes. Mutation Research, 397(2), 137148.

[7]. Sweeney, M., Lyon, M. (1999). Selective effect of malathion on blood coagulation versus locomotor activity. Journal of Environmental Pathology, Toxicology and Oncology, 18(3), 2003-2011.

[8]. Rupa, D.S., Reddy, P.P., Reddy, O.S. (1989). Frequencies of chromosomal aberrations in smokers exposed to pesticides in cotton field. Mutation Research, 222(1), 37-41.

[9]. Garry, V.F., Nelson, R.L., Griffith, J., Harkins, M. (1990). Preparation for human study of pesticide applicators: Sister chromatid exchanges and chromosome aberration in cultured human lymphocytes exposed to selected fumigants. Teratogenesis Carcinogeneis Mutagenesis, 10, 21-29.

[10]. Ragnarsdottir, K.V. (2000). Environmental fate and toxicology of organophosphate pesticides. Journal of the Geological Society London, 157, 859-876. https://doi.org/10.1144/jgs.157.4.859

[11]. Degraeve, N., Moutschen, J. (1984). Genetic and cytogenetic effects induced in the mouse by an organophosphorus insecticide: malathion. Environment Research, 34(1), 1704.

[12]. LeBlanc, G.A., Bain, L.J. (1997). Chronic toxicity of environmental contaminants: sentinels and biomarkers. Environmental Health Perspective, 105, 65-80.

[13]. Iwen, P.C., Hinrichs, S.H., Rupp, M.E. (2002). Utilization of the internal transcribed spacer regions as molecular targets to detect and identify human fungal pathogens. Medical Mycology, 40(1), 87-109. https://doi.org/10.1080/mmy.40.1.87.109.

[14]. Long, E.O., Dawid, I.B. (1980). Repeated genes in eukaryotes. Annual Review of Biochemistry, 49, 727-64. DOI: 10.1146/annurev.bi.49.070180.003455

[15]. Perry, R.P. (1976). Processing of RNA. Annual Review of Biochemistry, 45, 605-29. DOI: 10.1146/annurev.bi.45.070176.003133

[16]. Musters, W., Boon, K., van der Sande, C.A., van Heerikhuizen, H., Planta, R.J. (1990). Functional analysis of transcribed spacers of yeast ribosomal DNA. EMBO Journal, 9(12), 3989-96.

[17]. Clements, A.N. (1996). The biology of mosquitoes. Vol. 1. London: Chapman and Hall.

[18]. Singh, K.R., Patterson, R.S., La-Brecque, G.C., Razdan, R.K. (1975). Mass rearing of Culex pipiens fatigans Weid. Journal of Communicable Diseases, 7, 31-53.

[19]. Finney, D.J. (1971). Probit analysis. 2nd ed. UK: Cambridge University Press.

[20]. Ausubel, F.M., Brent, R., Kingston, R.E., Moore, D. D. (1999). Short protocols in molecular biology. 4th ed. New York: JohnWiley and Sons.

[21]. Shouche, Y.S., Patole, M.S. (2000). Sequence analysis of mitochondrial 16S ribosomal RNA gene fragment from seven mosquito species. Journal of Biosciences, 25, 361-366. https://doi.org/10.1007/BF02703789.

[22]. Porter, C. H., Collins, F.H. (1991). Species diagnostic difference in a ribosomal DNA internal transcribed spacer from the sibling species Anopheles freeborni and Anopheles hermsi (Diptera: Culicidae). The American 
Journal of Tropical Medicine and Hygiene, 45, 271-279.

[23]. Insecticide factsheet (2003). Northwest Coalition For Alternatives To Pesticides/NCAP. P.O.Box 1393, eugene, oregon 97440/(541) 344 - 5044. Journal of Pesticide Reform/ Winter, 23(4), 10-15.

[24]. Richendrfer, H., Creton, R. (2015). Chlorpyrifos and malathion have opposite effects on behaviors and brain size that are not correlated to changes in $\mathrm{AChE}$ activity. Neurotoxicology, 49, 50-58. https://doi.org/10.1016/j.neuro.2015.05.002

[25]. Anzecc and Armcanz (2000). Australian and New Zealand guidelines for fresh and marine water quality. Australian and New Zealand environment and conservation council and agriculture and resource management council of Australia and New Zealand, Canberra. https://www.waterquality.gov.au/anzguidelines/guideline-values/default/waterquality-toxicants/toxicants/malathion-2000. Last accessed on 14.04.2020.

[26]. Giri, S., Prasad, S.B., Giri, A., Sharma, G.D. (2002). Genotoxic effects of malathion: an organophosphorus insecticide, using three mammalian bioassays in vivo. Mutation Research-Genetic Toxicology and Environmental, 514(1-2), 223-231.

[27]. Muturi, E.J., Lampman, R., Costanzo, K., Alto, B.W. (2011). Effect of temperature and insecticide stress on life-history traits of Culex restuans and Aedes albopictus (Diptera: Culicidae). Journal of Medical Entomology, 48, 243-250.

[28]. Ullah, S., Li, Z., Hasan, Z., Khan, S.U., Fahad, S. (2018). Malathion induced oxidative stress leads to histopathological and biochemical toxicity in the liver of rohu (Labeo rohita, Hamilton) at acute concentration. Ecotoxicol. Environ. Safe., 161: 270-280.

[29]. HSDB (Hazardous Substances Data Bank) 1996. Micromedex Inc. 31 July 1996.

[30]. Lien, N.T.H., Adriaens, D., Janssen, C. (1997). Morphological abnormalities in African catfish (Clarias gariepinus) larvae exposed to malathion. Chemosphere 35(7), 1475-86. DOI: 10.1016/S0045-6535(97)00208-7

[31]. Bhinder, P., Chaudhry, A. (2013). Mutagenicity assessment of organophosphates using polymerase chain reaction-restriction fragment length polymorphism assay. Toxicology International, 20(3), 254-260. https://doi.org/10.4103/0971-6580.121678.

[32]. Bhinder, P., Chaudhry, A. (2014). Genotoxicity evaluation of acephate and profenofos by the PCR-RFLP assay. Toxicology International, 21(1), 84-88. https://doi.org/10.4103/0971-6580.128809.

[33]. Johnson, W.W., Finley, M.T. (1980). Handbook of acute toxicity of chemicals to fish and aquatic invertebrates. US Department of the Interior, Fish and Wildlife Service, No 137, Washington DC

[34]. Khan, H.A.A, Akram, W. (2014). The effect of temperature on the toxicity of insecticides against Musca domestica L.: implications for the effective management of diarrhea. PLoS One. 9(4), e95636. doi: 10.1371/journal.pone.0095636.

[35]. Kalender, S., Uzun, F.C., Durak, D., Demir, F., Kalender, Y., 2010. Malathion-induced hepatotoxicity in rats: The effects of vitamins $\mathrm{C}$ and E. Food and Chemical Toxicology, 48(2), 633-638.

[36]. Severcan, Ç., Ekremoglu, M., Sen, B., Pasaoglu, O., Akyurek, N., Severcan, S., Pasaoglu, H. (2019). Acute effects of different doses of malathion on the rat liver. Clinical and Experimental Hepatology, 5(3), 237-243. https://doi.org/10.5114/ceh.2019.87637.

[37]. Uzun, F.G., Kalender, S., Durak, D., Demir, F., Kalender, Y. (2009). Malathion-induced testicular toxicity in male rats and the protective effect of vitamins $\mathrm{C}$ and E. Food and Chemical Toxicology, 47(8), 1903-1908.

[38]. Yokota, K., Fukuda, M., Katafuchi, R., Okamoto, T. (2017). Nephrotic syndrome and acute kidney injury induced by malathion toxicity. BMJ case reports, bcr2017220733. https://doi.org/10.1136/bcr-2017-220733

[39]. Al-Attar, A.M. (2010). Physiological and histopathological investigations on the effects of alpha-lipoic acid in rats exposed to malathion. Journal of Biomedicine and Biotechnology, 203503. https://doi.org/10.1155/2010/203503

[40]. Kumar, R., Nagpure, N.S., Kushwaha, B., Srivastava, S.K., Lakra, W.S. (2010). Investigation of the genotoxicity of malathion to freshwater teleost fish Channa punctatus (Bloch) using the micronucleus test and comet assay. Archeives of Environmental Contamination and Toxicology, 58(1),123-30. doi: 10.1007/s00244-009-9354-3.

[41]. Ullah, S., Begum, M., Dhama, K., Ahmad, S., Hassan, S., Alam, I. (2016b). Malathion induced DNA damage in freshwater fish, Labeo rohita (Hamilton, 1822) using alkaline single cell gel electrophoresis. Asian Journal of Animal and Veterinary Advances,11, 98105 . 